\title{
Genetic disruption of both Chlamydomonas reinhardtii [FeFe]-hydrogenases: Insight into the role of HYDA2 in $\mathrm{H} 2$ production
}

\section{Authors: Jonathan E. Meuser, Sarah D'Adamo, Robert E. Jinkerson, Florence Mus, Wenqiang Yang, Maria L. Ghirardi, Michael Seibert, Arthur R. Grossman, \& Matthew C. Posewitz}

NOTICE: this is the author's version of a work that was accepted for publication in Biochemical and Biophysical Research Communications. Changes resulting from the publishing process, such as peer review, editing, corrections, structural formatting, and other quality control mechanisms may not be reflected in this document. Changes may have been made to this work since it was submitted for publication. A definitive version was subsequently published in Biochemical and Biophysical Research Communications, 417, 2, January 2012. DOI\#10.1016/j.bbrc.2011.12.002.

Meuser JE, D'Adamo S, Jinkerson RE, Mus F, Yang W, Ghirardi ML, Seibert M, Grossman AR, Posewitz MC, "Genetic disruption of both Chlamydomonas reinhardtii [FeFe]-hydrogenases: Insight into the role of HYDA2 in $\mathrm{H} 2$ production," Biochemical and Biophysical Research Communications, January 2012 417(2):704-709 


\title{
Genetic disruption of both Chlamydomonas reinhardtii [FeFe]-hydrogenases: Insight into the role of HYDA2 in $\mathrm{H}_{2}$ production
}

\author{
Jonathan E. Meuser ${ }^{a}$, Sarah D'Adamo ${ }^{b}$, Robert E. Jinkerson ${ }^{b}$, Florence Mus $d, e, 1$, \\ Wenqiang Yang ${ }^{\mathrm{c}}$, Maria L. Ghirardi ${ }^{\mathrm{f}}$, Michael Seibert $\mathrm{b}, \mathrm{f}$, Arthur R. Grossman ${ }^{\mathrm{c}}$, \\ Matthew C. Posewitz ,* \\ a Department of Civil and Environmental Engineering, Colorado School of Mines, Golden, CO 80401, USA \\ $\mathrm{b}$ Department of Chemistry and Geochemistry, Colorado School of Mines, Golden, CO 80401, USA \\ ${ }^{\mathrm{c}}$ Carnegie Institution for Science, Department of Plant Biology, 260 Panama Street, Stanford, CA 94305, USA \\ d Department of Microbiology, Montana State University, Bozeman, MT 59717, USA \\ e Department of Chemical and Biological Engineering, Montana State University, Bozeman, MT 59717, USA

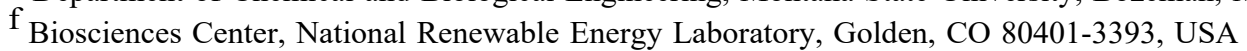

\begin{abstract}
Chlamydomonas reinhardtii (Chlamydomonas throughout) encodes two [FeFe]-hydrogenases, designated HYDA1 and HYDA2. While HYDA1 is considered the dominant hydrogenase, the role of HYDA2 is unclear. To study the individual functions of each hydrogenase and provide a platform for future bioengineering, we isolated the Chlamydomonas hydA1-1, hydA2-1 single mutants and the hydA1-1 hydA2-1 double mutant. A reverse genetic screen was used to identify a mutant with an insertion in HYDA2, followed by mutagenesis of the hydA2-1 strain coupled with a $\mathrm{H}_{2}$ chemosensor phenotypic screen to isolate the hydA1-1

hydA2-1 mutant. Genetic crosses of the hydA1-1 hydA2-1 mutant to wild-type cells allowed us to also isolate the single hydA1-1 mutant. Fermentative, photosynthetic, and in vitro hydrogenase activ-ities were assayed in each of the mutant genotypes. Surprisingly, analyses of the hydA1-1 and hydA2-1 single mutants, as well as the HYDA1 and HYDA2 rescued hydA1-1 hydA2-1 mutant demonstrated that both hydrogenases are able to catalyze $\mathrm{H}_{2}$ production from either fermentative or photosynthetic path-ways. The physiology of both mutant and complemented strains indicate that the contribution of HYDA2 to $\mathrm{H}_{2}$

photoproduction is approximately $25 \%$ that of HYDA1, which corresponds to similarly low

levels of in vitro hydrogenase activity measured in the hydA1-1 mutant. Interestingly, enhanced in vitro and fer-mentative $\mathrm{H}_{2}$ production activities were observed in the hydA1-1 hydA2-1 strain complemented with HYDA1, while maximal $\mathrm{H}_{2}$-photoproduction rates did not exceed those of wild-type cells.
\end{abstract}

\section{Introduction}

Diverse bacteria and microbial eukaryotes, including many green algae, encode [FeFe]-hydrogenase (HYDA) enzymes that cat-alyze the reversible reduction of protons to $\mathrm{H}_{2}[1,2]$. Anaerobic $\mathrm{H}_{2}$ production in green algae (s.s. Chlorophyta), such as Chlamydo-monas reinhardtii (Chlamydomonas throughout), can be generally classified into three distinct pathways: a low-production, fermen-tative pathway linked to carbohydrate catabolism, and two distinct photosystem-linked pathways [photosystem II (PSII)-dependent and PSII-independent] [3]. PSIIdependent $\mathrm{H}_{2}$ photoproduction is limited by inactivation of the native algal hydrogenases by $\mathrm{O}_{2}$ $[4,5]$. The $\mathrm{O} 2$ sensitivity of algal hydrogenases is likely a regulatory feature that helps to direct electron flow for the greatest competi-tive benefit to the alga in the natural environment. Hydrogenases likely serve as an "electron valve", when $\mathrm{H} 2$ photoproduction rates are highest during the transition from anoxia to aerobic photosynthesis [6]. However, sustained aerobic $\mathrm{H}_{2}$ photoproduction repre-sents an energetically wasteful process. If the natural regulation of $\mathrm{H}_{2}$ production in green algae, including $\mathrm{O}_{2}$ sensitivity and com-petition for electrons with other pathways, can be reengineered, the high quantum efficiencies by which algae can theoretically oxi-dize water to $\mathrm{H}_{2}$ [7] could be leveraged to produce a carbon-free fuel more efficiently than can be achieved using existing technol-ogy for carbon-based biofuel production by vascular plants.

Hydrogen metabolism in Chlamydomonas is catalyzed by two [FeFe]-hydrogenase (HYDA) paralogs, HYDA1 and HYDA2 [8,9]. Examination of relative enzyme activities by gene-silencing techniques indicate that HYDA1 catalyzes the majority of the in vitro hydrogenase activity, but revealed no evidence for a substantive role of HYDA2 in algal $\mathrm{H}_{2}$ production [10]. Interestingly, all green 
algae for which hydrogenase activity has been characterized contain at least two enzyme isoforms, with recent phylogenetic analysis suggesting that gene duplication events occurred independently in each alga [1]. This finding indicates that there has been selective pressure for duplicating and maintaining two copies of the hydrogenase, which may have evolved to have distinct functions.

We have undertaken a project focused on eliminating the activity of both HYDA1 and HYDA2 in Chlamydomonas by insertional mutagenesis to study the role of the two hydrogenases in algal metabolism and to establish a platform for the heterologous expression of hydrogenases in a system that is not complicated by native enzyme activity.

\section{Materials and methods}

\subsection{Algal cultures and growth conditions}

C. reinhardtii strain $\mathrm{CC} 124\left(\right.$ nit $\left.^{-}, \mathrm{mt}^{-}\right)$was obtained from the Chlamydomonas Genetic Center (http://www.chlamy.org/). C. reinhardtii strain D66 (nit ${ }^{-}, c w 15$, and $\left.m t^{+}\right)$[11] was obtained from Steven Pollock and used for mutant generation. For the physiological experiments, axenic algal cultures $(100 \mathrm{~mL})$ were inoculated at $10^{5}$ cells $/ \mathrm{mL}$ in $250 \mathrm{~mL}$ Erlenmeyer flasks capped with silicone sponge enclosures (Chemglass, Vineland, NJ, USA), grown in Tris-Acetate-Phosphate (TAP) medium [12], pH 7.2, and shaken at $120 \mathrm{rpm}$ under constant fluorescent irradiance (24 h photoperiod at $80 \mu \mathrm{mol}$ photon $\mathrm{m}^{-2} \mathrm{~s}^{-1}$ PAR by GE Ecolux 6500k T5 bulbs). Cells were harvested at $48 \mathrm{~h}$ post-inoculation during mid-logarithmic growth (16-24 $\mu \mathrm{g} \mathrm{Chl} / \mathrm{mL}$ ) for measuring in vitro and $\mathrm{H}_{2}$ photoproduction activities, and at $60 \mathrm{~h}$ post-inoculation (24$33 \mu \mathrm{g} \mathrm{Chl} / \mathrm{mL}$ ) for dark, fermentative $\mathrm{H}_{2}$ evolution measurements.

\subsection{Chlorophyll determination and cell count}

Chlorophylls were extracted in 95\% ethanol, cell debris pelleted by centrifugation ( $9000 \mathrm{~g}$ for $5 \mathrm{~min}$ ), and total Chl spectrophotometrically quantified [12]. Cell numbers were determined using a Beckman Z2 Coulter Counter (Beckman Coulter, Brea, CA, USA).

\subsection{Mutant generation, screening, and isolation}

D66 was first transformed with a $1.7 \mathrm{~kb}$ PCR-fragment, amplified from the pSL72 plasmid [13] using RIM-F2 (5'-ACCAATCGTCACACGAGC- $\left.3^{\prime}\right)$ and RIM-R2 (5'-CTTTCCATCGGCCCAGCAAC- $\left.3^{\prime}\right)$ primers and containing the AphVIII gene under the control of the PSAD promoter (Fig. 1A) Electroporation was performed using a modification of the procedure reported by Shimogawara et al. [13]. Briefly, cells were collected by centrifugation at $3000 \mathrm{~g}$ for $5 \mathrm{~min}$, resuspended in TAP medium supplemented with $40 \mathrm{mM}$ sucrose (TAP + sucrose) to a final cell density of $1-4 \times 10^{8}$ cells $/ \mathrm{mL}$, and $250 \mu \mathrm{L}$ of the suspension was placed into a disposable $4-\mathrm{mm}$ gap electroporation cuvette (Bio-Rad, Hercules, CA, USA). Marker gene DNA was resolved by electrophoresis in $1 \%$ agarose gels, excised, and purified using the QIAquick PCR Purification Kit (Qiagen, Valencia, CA, USA). Purified marker gene DNA (100 ng) was added to the cell suspension in the electroporation cuvette and incubated at $4{ }^{\circ} \mathrm{C}$ for $10 \mathrm{~min}$. An exponential electric pulse of $0.8 \mathrm{kV}$ at a capacitance of $25 \mu \mathrm{F}$ was applied to the sample using the Gene Pulser II (Bio-Rad) electroporation apparatus. Following electroporation, cells were transferred to $10 \mathrm{~mL}$ of fresh liquid TAP medium and incubated for $16-18 \mathrm{~h}$ at $23^{\circ} \mathrm{C}$ under dim light. The cells were then centrifuged (3000g for $5 \mathrm{~min}$ ), resuspended in $1 \mathrm{~mL}$ of TAP medium, spread onto selective TAP medium $(5 \mu \mathrm{g} / \mathrm{mL}$ paromomycin, $1.2 \%$ agar), and incubated for $1-2$ weeks ( $24 \mathrm{~h}$ photoperiod at

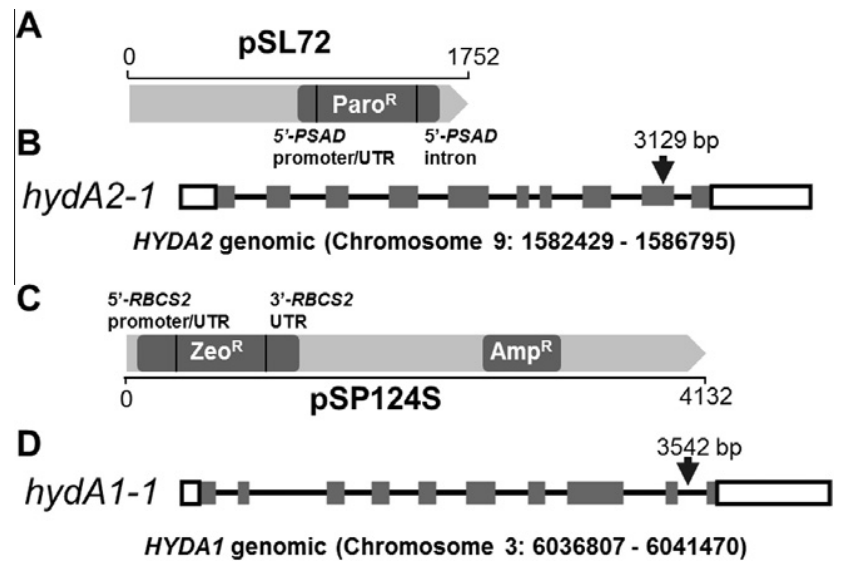

Fig. 1. (A) pSL72 vector used for the generation of the hydA2-1 mutant. (B) hydA2-1 gene showing the site of gene disruption (arrow), which is in exon 9. (C) pSP124S vector used for generation of the hydA1-1 hydA2-1 mutant, and (D) hydA1-1 gene showing the site of gene disruption (arrow). Grey boxes represent exons, black lines represent introns, and white boxes represent $5^{\prime}$-, 3'-UTRs.

$60 \mu \mathrm{mol}$ photon $\mathrm{m}^{-2} \mathrm{~s}^{-1}$ PAR). Single colonies were picked and transferred to $200 \mu \mathrm{L}$ of liquid TAP medium in individual wells of 96-well microtiter plates. Transformant screening for marker gene insertion within the HYDA2 gene was as described previously $[14,15]$ using primers (Supplementary Table 1 ) designed with Primer 3 software [16].

\subsection{Phenotypic screening for the hydA1-1/hydA2-1 mutant}

To isolate the hydA1-1 hydA2-1 mutant, a secondary screen was performed. The pSP124S plasmid (Fig. 1C), which confers Zeo ${ }^{\mathrm{R}}$, was purified using the Qiagen Plasmid Mini Kit (Qiagen), Swa1-linearized and concentrated to approximately $1 \mu \mathrm{g} / \mu \mathrm{L}$ using the QIAquick MinElute Gel Extraction Kit (Qiagen). The hydA2-1 mutant cells were grown to $10-25 \mu \mathrm{g} \mathrm{Chl} / \mathrm{mL}, 50 \mathrm{~mL}$ of cells were pelleted by centrifugation ( $3160 \mathrm{~g}$ for $5 \mathrm{~min}$ ) and resuspended in $100 \mu \mathrm{L}$ of sterile TAP + sucrose and $1 \mu \mathrm{g}$ of plasmid DNA. The resulting $250 \mu \mathrm{L}$ volume was transferred to a 4-mM gap electroporation cuvette (Eppendorf, Hauppauge, NY, USA) and incubated on ice for 15 min prior to electroporation using an ECM 630 electroporator (BTX Genetronics, San Diego, CA, USA) with settings of $0.8 \mathrm{kV}$, $1575 \Omega$ and $25 \mu \mathrm{F}$. Immediately following electroporation, cells were transferred to $10 \mathrm{~mL}$ of TAP + sucrose and placed in dim light $\left(20 \mu \mathrm{mol}\right.$ photon $\mathrm{m}^{-2} \mathrm{~s}^{-1}$ PAR) on an orbital shaker for $16-18 \mathrm{~h}$. The cells were then centrifuged ( $3160 \mathrm{~g}$ for $5 \mathrm{~min}$ ), resuspended in $1 \mathrm{~mL}$ of TAP + sucrose medium, and plated on selective TAP medium ( $3.3 \mu \mathrm{g} / \mathrm{mL}$ Zeocin, $1.2 \%$ agar). Following drying in a sterile hood, the plates were placed under constant illumination (50 $\mu \mathrm{mol}$ photon $\mathrm{m}^{-2} \mathrm{~s}^{-1}$ PAR) for 1-2 weeks until individual colonies were transferred onto fresh plates. Colonies were allowed to grow for $1-2$ weeks under constant illumination $(20 \mu \mathrm{mol}$ photons $\mathrm{m}^{-2} \mathrm{~s}^{-1} \mathrm{PAR}$ ) before screening for $\mathrm{H}_{2}$-photoproduction activity. The screen involved physical vapor deposition of PTFE/Pd/ $\mathrm{WO}_{3}$ onto glass plates to produce chemochromic $\mathrm{H}_{2}$ sensors $[5,17,18]$. The colonies were excluded from light within velvet bags and anaerobically-adapted by filling and evacuating the air lock of an anaerobic chamber (COY Laboratory Products Inc., Grass Lake, MI, USA) nine times with ultra-high-purity (UHP) $\mathrm{N}_{2}$ gas. All pressurized gases were obtained from General Air (Denver, CO, USA). The colonies were stored under a slightly positive pressure in UHP $\mathrm{N}_{2}$ for 2-4 h before the $\mathrm{H}_{2}$ photoproduction assay. The assay involved chemochromic sensors atop autoclaved \#2 filter paper (Whatman Inc.) placed directly in contact with the colonies 
immediately before exposure to $380 \mu \mathrm{mol}$ photon $\mathrm{m}^{-2} \mathrm{~s}^{-1}$ PAR incandescent light for $3 \mathrm{~min}$. Colonies negative for $\mathrm{H}_{2}$-photoproduction were recovered, including the hydA1-1 hydA2-1 mutant.

The original hydA1-1 hydA2-1 mutant was backcrossed four times [19] to Chlamydomonas strains CC124 and D66, always selecting for both Paro ${ }^{\mathrm{R}}$ and $\mathrm{Zeo}^{\mathrm{R}}$. From the final cross, progenies were selected for (a) Zeo ${ }^{\mathrm{R}}$, (b) $\operatorname{Paro}^{\mathrm{R}}$, or (c) both $\mathrm{Paro}^{\mathrm{R}}$ and $\mathrm{Zeo}^{\mathrm{R}}$, which represent the hydA1-1, hydA2-1, and hydA1-1 hydA2-1 mutants, respectively. PCR was used to define the mating type of the progeny and confirm sexual crossing using previously described primers [20] and, after the progeny of the backcrossed strains were selected on the basis of antibiotic resistance, to demonstrate that each strain had the expected disruption phenotype. Two $m t$-progeny from the final backcross that exhibited no antibiotic resistance and no insertions in HYDA genes (based on PCR) were selected as WT control strains. The mutant phenotypes described were from two selected progeny of each genotype (WT, hydA1-1, hydA2-1, and hydA1-1 hydA2-1). For each of these progeny, data from 4 independent experiments were averaged ( $n=8$ in total).

\subsection{Genomic isolation and gene identification}

Genomic DNA was isolated using the phenol:chloroform technique of Newman et al. [21], and DNA upstream of the pSP124S insertion site in HYDA1 was amplified by genome walking (Genome-Walker Universal Kit, Clontech, Mountain View, CA, USA). A fragment from a Pvull-digested genomic DNA library was used as a template to amplify a product with the sequence for the AP1 (5'-GTAATACGACTCACTATAGGGC-3') and nested AP3 (5'-CGTGGTCGACGGCCCGGG-3') adapter primers, and the Ble3F (5'-GCGAAGTCGTCCTCCACGAAGTC-3') and nested Ble4F (5'-GCCGGTCGGTCCAGAACTCG-3') primers, which were designed to specifically anneal to the $\mathrm{Zeo}^{\mathrm{R}}$ gene (ble) [22]. The downstream region flanking the site of DNA insertion (from 3004 to 3749 bp of HYDA1) was mapped by PCR methods on genomic DNA isolated from the hydA1-1 hydA2-1 mutant, using HYDA1 gene-specific primers (below) that anneal to different regions of the full-length genomic sequence. DNA regions flanking the pSP124S insertion site were precisely determined using a HYDA1 specific primer ( $3^{\prime} \mathrm{R} 3$ : 5'GGAGAAGGACGAGAAGAAGTGAGG-3') and a pSP124S specific primer (GSP1-R: 5'-CAAAATCAACGGAGGATCGTTACA-3') to amplify across the site at which the marker gene inserted. For primary and secondary PCRs on DNA fragments of the Pvull-digested library, we used AP1 and AP3 nested primers, each with a single HYDA1 gene-specific primer (3'F2: 5'-AAGAAGCTGATCACCAAGATGCAG- $3^{\prime}$ ). All of the PCRs were performed using the KOD HotStart Mastermix (EMD Chemical, Gibbstown, NJ, USA), and the products generated were sequenced (Davis Sequencing, Davis, CA, USA).

\subsection{Complementation}

BAC clones containing the HYDA1 and HYDA2 full-length genomic sequences (including $5^{\prime}$ and $3^{\prime}$ predicted UTRs) were obtained from the Clemson University Genetics Center. The HYDA2 gene, including the $5^{\prime}$ and $3^{\prime}$ predicted UTRs, was excised from the BAC clone (1G24) with ZraI and then cloned into the pUC19 plasmid (New England Biolabs, Ipswich, MA, USA); the AphVII gene, which confers Hygromycin B resistance $\left(\operatorname{Hyg}^{\mathrm{R}}\right)$, was isolated from pHyg3 [23] (generously provided by Patrice Hamel) by HindIII digestion and subcloned into the pUC19:HYDA2 plasmid, yielding the pUC19:HYDA2:AphVII plasmid pSD1928. This plasmid was linearized with ScaI, the DNA was dephosphorylated with Antarctic Phosphatase (New England Biolabs), and the fragment was resolved by agarose gel electrophoresis and purified from the gel using the QIAquick DNA Gel Extraction Kit (Qiagen). Transformation into the hydA1-1 hydA2-1 mutant was performed by electroporation as described above. Transformants were selected on TAP plates containing $10 \mu \mathrm{g} / \mathrm{mL}$ of Hygromycin B (Sigma-Aldrich, St. Louis, MO, USA).

For introduction of HYDA1 into the hydA1-1 hydA2-1 mutant, a BAC clone (34H3) was digested with NotI, and the fragment containing the full-length genomic HYDA1 sequence (including $5^{\prime}$ and $3^{\prime}$ predicted UTRs) was cloned into pSP124S at the NotI site. The ble gene was then excised from the plasmid with HindIII and replaced with the AphVII gene such that the plasmid confers $\mathrm{Hyg}^{\mathrm{R}}$. This plasmid was then digested with XbaI, the DNA ends dephosphorylated, the linearized plasmid resolved by electrophoresis (1.2\% agarose gel) and purified from the agarose with the QIAquick Gel Extraction Kit (Qiagen). Electroporation was performed as described above, and the transformants were selected on TAP plates containing $10 \mu \mathrm{g} / \mathrm{mL}$ of Hygromycin B.

\subsection{Anaerobic induction}

Liquid cell cultures (20-50 mL) were concentrated by centrifugation ( $3716 \mathrm{~g}$ for $10 \mathrm{~min}$ ) and resuspended in 0.1 volume of anaerobic induction buffer [AIB ( $50 \mathrm{mM}$ potassium phosphate, $\mathrm{pH}$ 7.2; $\left.3 \mathrm{mM} \mathrm{MgCl}_{2}\right)$ ]. Concentrated cells $(2-5 \mathrm{~mL}$ ) were transferred to aluminum foil-covered, butyl rubber septa-sealed, $13-\mathrm{mL}$ glass serum vials and purged vigorously with UHP Ar for $30 \mathrm{~min}$ to establish anoxia. Following purging, the cells were incubated with no agitation at room temperature $\left(25^{\circ} \mathrm{C}\right)$ for the times indicated. All transfers of cells, solutions, and gases were performed using UHP Ar-flushed, gas-tight syringes (Hamilton Company, Reno, NV, USA).

\section{8. $\mathrm{H}_{2}$ photoproduction}

Maximal in vivo $\mathrm{H}_{2}$-photoproduction rates were determined using a Pt- $\mathrm{Ag} / \mathrm{AgCl}$ polarographic electrode system (ALGI, Golden, CO, USA) equipped with a temperature-controlled, water-jacketed 1-mL glass cell and a commercially-available YSI 5331 electrode (Yellow Springs Instruments, Yellow Springs, OH, USA) poised at $+0.6 \mathrm{~V}$. One hundred microliters of 10 -fold concentrated, anaerobically-acclimated cells were diluted in $900 \mu \mathrm{L}$ of UHP Ar-purged, $50 \mathrm{mM}$ 3-morpholinopropanesulfonic acid (MOPS), pH 6.9. As previously described [24], a 30 s dark: 90 s light: 30 s dark regime using saturating LED (Luxeon III Star, Lumileds, San Jose, CA, USA) irradiance of $2000 \mu \mathrm{mol}$ photon $\mathrm{m}^{-2} \mathrm{~s}^{-1}$ PAR was used to determine maximal $\mathrm{H}_{2}$-photoproduction rates. The electrode was calibrated before each measurement using a $50 \mathrm{mM}$ MOPS solution purged with UHP 5\% $\mathrm{H}_{2}$ (Ar balance) and then UHP Ar to determine the $\mathrm{H}_{2}$ response and baseline, respectively.

\subsection{In vitro hydrogenase activity}

MV assays for hydrogenase activity were performed at 4 and $24 \mathrm{~h}$ post-Ar-purging by transferring $100 \mu \mathrm{L}$ of the anaerobicallyadapted cells to a $1.2 \mathrm{~mL}$ solution of Ar-purged sodium dithionitereduced MV [ $1 \mathrm{~mL}$ of MV solution (10 mM MV; $50 \mathrm{mM}$ potassium phosphate, pH 6.9; $0.2 \%$ Triton X-100) plus $200 \mu \mathrm{L}$ of freshly-prepared $100 \mathrm{mM}$ sodium dithionite in $30 \mathrm{mM} \mathrm{NaOH}$ (all obtained from Sigma-Aldrich)] in sealed, Ar-purged, 13-mL vials. Reactions were incubated at $37^{\circ} \mathrm{C}$ in a shaking ( 160 cycles $\mathrm{min}^{-1}$ ) water bath (Boekel Grant ORS200) for 2-10 min before $100 \mu \mathrm{L}$ of headspace gas was assayed by gas chromatography as previously described [5].

\subsection{Dark hydrogenase activity}

Following periods of dark, anaerobic acclimation, $0.2 \mathrm{~mL}$ of headspace gas was removed using an UHP Ar-purged Hamilton 
gas-tight syringe (Hamilton Company) and analyzed by gas chromatography.

\section{Results}

Fig. 2A shows in vitro methyl viologen mediated hydrogenase activity for each of the mutants and the WT control. These data provide direct insights into the levels of active enzyme present. Low levels of in vitro activity $(<25 \%)$ were observed in strains containing only HYDA2, while activities similar to that of WT were catalyzed in the mutant with only HYDA1. Only $0.1-0.5 \%$ of maximal
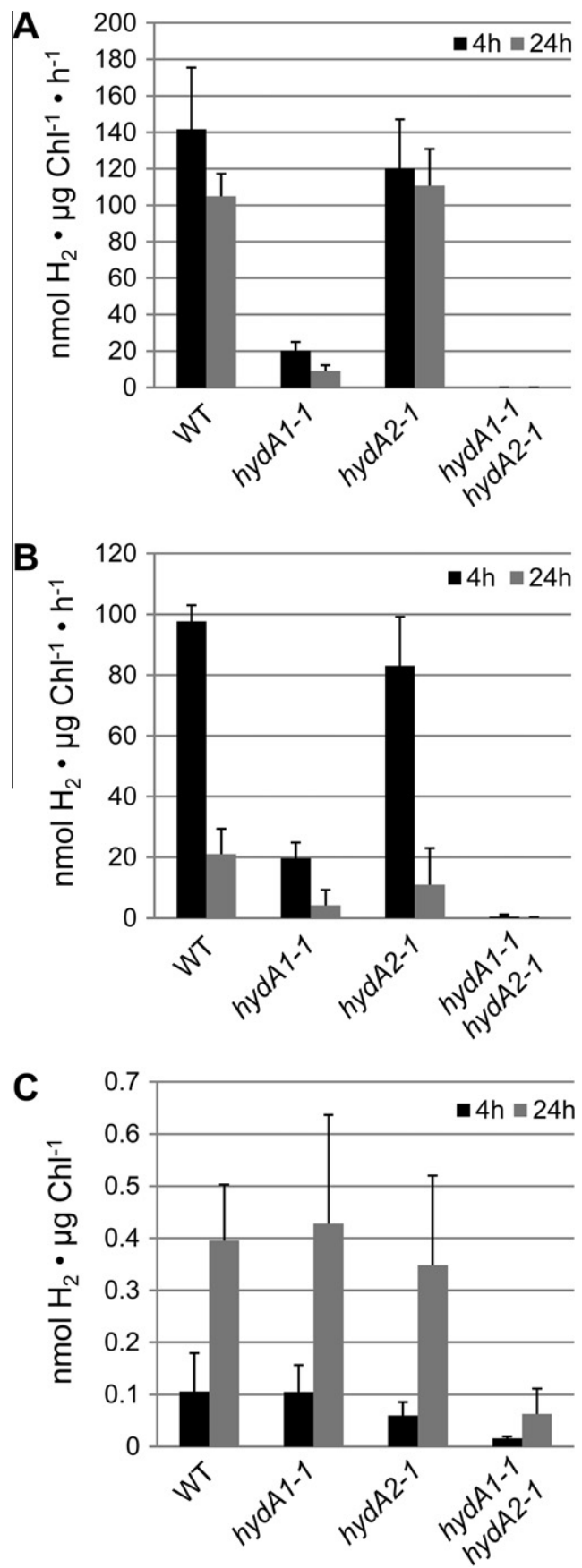

Fig. 2. Hydrogenase activities in the WT, single hydrogenase mutants (hydA1-1 and hydA2-1), and the hydA1-1 hydA2-1 mutant following 4 and $24 \mathrm{~h}$ of anoxia. (A) MVmediated, in vitro HYDA activities. (B) Maximal initial $\mathrm{H}_{2}$ photoproduction rates. (C) Total dark, anaerobic $\mathrm{H}_{2}$ accumulation.
WT hydrogenase activity (Fig. 2A-C) was observed in the hydA1-1 hydA2-1 mutant, activity that is not observed in either the hydEF-1 [18] or hydG-1 mutants [24], which are devoid of the required hydrogenase maturation enzymes. The remaining activity may be the consequence of low levels of HYDA1, as the HYDA1 gene contains an insertion that is confined to an intron. Hydrogenase activity can be restored to the levels observed in the single mutant strains if either HYDA1 or HYDA2 are expressed ectopically in the double mutant, as shown in Fig. 3.

As shown in Fig. 2B, each HYDA isoform contributes to $\mathrm{H}_{2}$ photoproduction at levels that paralleled in vitro activity measurements (Fig. 2A). While HYDA2 clearly contributes to $\mathrm{H}_{2}$ photoproduction, WT levels of production, or greater, are only observed in double mutant strains rescued with the HYDA1 gene (Fig. 3); these rates of production are never attained in strains that only harbor HYDA2. Despite the higher than WT level of in vitro activities observed in the double mutant rescued by introduction of HYDA1 (Fig. 3), these strains show maximal in vivo $\mathrm{H}_{2}$-photoproduction rates that are similar to the WT, support for the conclusion that the hydrogenase enzyme level may not be the primary factor limiting in vivo $\mathrm{H}_{2}$ photoproduction [25].

Total dark, anaerobic $\mathrm{H}_{2}$ production in the hydrogenase mutants did not parallel the patterns of in vitro activity (compare Fig. 2C with A). Instead, the levels of dark, fermentative $\mathrm{H}_{2}$ that were produced by both hydA1-1 and hydA2-1 were similar to that of WT, indicating that the very low levels of $\mathrm{H}_{2}$ generated by dark, anaerobic Chlamydomonas cells can be catalyzed by the native activity of either hydrogenase paralog. Furthermore, the natural fermentative $\mathrm{H}_{2}$ flux is sufficiently low such that even in the hydA1-1 hydA2-1 mutant approximately $10 \%$ of WT dark $\mathrm{H}_{2}$ production is observed (Fig. 2C). Conversely, the hydA1-1 hydA2$1:: H Y D A 1$ rescued strain (Fig. 3 ) showed enhanced fermentative $\mathrm{H}_{2}$ production; however, the production levels were still low with respect to the molar levels of the primary fermentative products (formate, acetate, and ethanol) [5]. Similarly, the low WT levels of dark, fermentative $\mathrm{H}_{2}$ production could be restored by HYDA2 expression in the hydA1-1 hydA2-1 mutant alone (Fig. 3). Thus, when expressed using its native promoter, HYDA2 is insufficient to drive maximal $\mathrm{H}_{2}$ photoproduction; however, it is sufficient to oxidize all of the reductant trafficked to $\mathrm{H}_{2}$ production during dark fermentation.

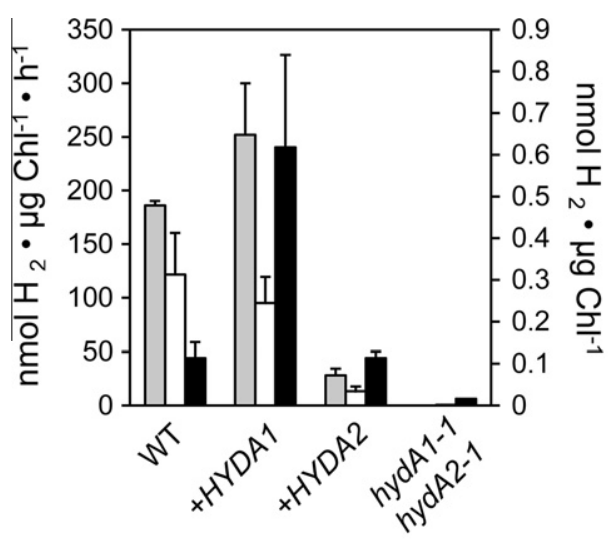

$\square$ Methyl viologen (in vitro) $\mathrm{H}_{2}$ production

Maximal $\mathrm{H}_{2}$ photoproduction

Dark, anaerobic $\mathrm{H}_{2}$ production

Fig. 3. Hydrogenase activities of WT cells, the hydA1-1 hydA2-1 mutant and the double mutant complemented with HYDA1 and HYDA2 following $4 \mathrm{~h}$ of anaerobiosis. Dark, anaerobic production activities (black columns) are reported on the right axis, with MV-activity (gray columns) and maximum $\mathrm{H}_{2}$ photoproduction (white columns) on the left axis. 


\section{Discussion}

While an efficient biological system that directly converts solar flux to $\mathrm{H}_{2}$ is theoretically feasible, it may not exist in nature because there may be little selective pressure favoring such a pathway. While the high maximal $\mathrm{H}_{2}$-photoproduction rates observed in Chlamydomonas may be related to characteristics of the truncated hydrogenases that are specifically present in Chlorophycean algae, the extreme $\mathrm{O}_{2}$ sensitivity of these small ( $\sim 48 \mathrm{kD}$ ) hydrogenases is likely a function of these enzymes that is necessary to prevent the wasteful loss of cellular reductant. Although the occurrence of algal $\mathrm{H}_{2}$ photoproduction suggests the possibility of exploiting such a system for energy production, the high initial rates of $\mathrm{H}_{2}$ synthesis are not sustained because of $\mathrm{O}_{2}$ inhibition and competition among diverse metabolic pathways, including photosynthetic carbon fixation. Towards the goal of generating a system for sustainable $\mathrm{H}_{2}$ production, our work provides a genetic background suitable for approaches that utilize heterologous expression of non-native and engineered hydrogenases in a Chlamydomonas strain free of the complications associated with the presence of endogenous hydrogenase activity.

The principal aim of the present study was to generate and characterize null mutants in each HYDA gene of Chlamydomonas in order to evaluate the relative contributions of HYDA1 and HYDA2 in Chlamydomonas $\mathrm{H}_{2}$ production. The function of HYDA2 in Chlamydomonas $\mathrm{H}_{2}$ metabolism has been enigmatic, with no clear physiological role revealed by either amiRNA analysis [10], or biochemical approaches [26]. Although HYDA2 transcript levels accumulate over 50 -fold in response to anoxia ( $20 \%$ of the increase observed for the HYDA1 transcript) [27], its contribution and role(s) in Chlamydomonas $\mathrm{H}_{2}$ production was not known prior to this analysis. This study is the first to unequivocally demonstrate that HYDA2 accepts reductant from dark fermentation and the photosynthetic electron transport chain, however; only native HYDA1 activity can sustain maximal rates of $\mathrm{H}_{2}$ photoproduction (Fig. 2B).

Our results demonstrate that HYDA1 and HYDA2 can independently catalyze both light and dark $\mathrm{H}_{2}$ production. The HYDA1 enzyme can sustain near WT levels of $\mathrm{H}_{2}$ photoproduction and, when inserted in the double mutant background, can allow for elevated $\mathrm{H}_{2}$ synthesis relative to WT cells under dark anaerobic conditions; this latter finding suggests that elevated HYDA1 levels allow the enzyme to more effectively compete for reductant during dark fermentation. Interestingly, while the transgenic insertion of the native HYDA1 gene resulted in increased in vitro activities (Fig. 3), in vivo $\mathrm{H}_{2}$-photoproduction levels were not enhanced above that of the WT control, an indication that WT HYDA1 level/activity in Chlamydomonas may be natively matched to meet maximal reductant flow from the photosynthetic electron transport chain.

In summary, the combined activity data from the hydA mutants and complemented strains strongly support two major conclusions: (a) both HYDA enzymes are capable of coupling to fermentative and $\mathrm{H}_{2}$-photoproduction activities and (b) HYDA1 appears to be the physiologically dominant and more catalytically active $\mathrm{H}_{2}$-producing enzyme. Additionally, a Chlamydomonas genetic background is now available for interrogating numerous questions related to hydrogenase activities, their interactions with other proteins in the cell, as well as for the development of novel algal systems that exhibit elevated levels of $\mathrm{H}_{2}$ production.

\section{Acknowledgments}

The authors of this work gratefully acknowledge the US AFOSR Grants FA9550-05-1-0365 and FA9550-11-1-0211, NASA Grant NNG05GL52H, NSF Grants 0824469 and 0951094 and the US
DOE Office of Science Contract No. DE-AC3699G010337. We also acknowledge technical assistance from Alex Trujillo, Devin Karns, Randor Radakovits and Edward Dempsey.

\section{Appendix A. Supplementary data}

Supplementary data associated with this article can be found, in the online version, at doi:10.1016/j.bbrc.2011.12.002.

\section{References}

[1] J.E. Meuser, E.S. Boyd, G. Ananyev, D. Karns, R. Radakovits, U. Narayana Murthy, M.L. Ghirardi, G.C. Dismukes, J.W. Peters, M.C. Posewitz, Evolutionary significance of an algal gene encoding an [FeFe]-hydrogenase with F-domain homology and hydrogenase activity in Chlorella variabilis NC64A, Planta 234 (2011) 829-843.

[2] M.C. Posewitz, D.W. Mulder, J.W. Peters, New frontiers in hydrogenase structure and biosynthesis, Curr. Chem. Biol. 2 (2008) 178-199.

[3] M.C. Posewitz, A. Dubini, J.E. Meuser, M. Seibert, M.L. Ghirardi, Hydrogenases, hydrogen production and anoxia in Chlamydomonas reinhardtii, in: D. Stern, E.H. Harris (Eds.), The Chlamydomonas SourceBook, vol. 2, Elsevier, 2008, pp. 217-255.

[4] M. Ghirardi, R. Togasaki, M. Seibert, Oxygen sensitivity of algal $\mathrm{H}_{2}$-production, Appl. Biochem. Biotechnol. 63-65 (1997) 141-151.

[5] J.E. Meuser, G. Ananyev, L.E. Wittig, S. Kosourov, M.L. Ghirardi, M. Seibert, G.C. Dismukes, M.C. Posewitz, Phenotypic diversity of hydrogen production in chlorophycean algae reflects distinct anaerobic metabolisms, J. Biotechnol. 142 (2009) 21-30.

[6] B. Mahro, A.C. Küsel, L.H. Grimme, The significance of hydrogenase activity for the energy metabolism of green algae: anaerobiosis favours ATP synthesis in cells of Chlorella with active hydrogenase, Arch. Microbiol. 144 (1986) 91-95.

[7] M.L. Ghirardi, A. Dubini, J. Yu, P.-C. Maness, Photobiological hydrogenproducing systems, Chem. Soc. Rev. 38 (2009) 52-61.

[8] T. Happe, A. Kaminski, Differential regulation of the Fe-hydrogenase during anaerobic adaptation in the green alga Chlamydomonas reinhardtii, Eur. J. Biochem. 269 (2002) 1022-1032.

[9] M. Forestier, P. King, L. Zhang, M. Posewitz, S. Schwarzer, T. Happe, M.L. Ghirardi, M. Seibert, Expression of two [Fe]-hydrogenases in Chlamydomonas reinhardtii under anaerobic conditions, Eur. J. Biochem. 270 (2003) 2750-2758.

[10] J.E. Godman, A. Molnar, D.C. Baulcombe, J. Balk, RNA silencing of hydrogenase(-like) genes and investigation of their physiological roles in the green alga Chlamydomonas reinhardtii, Biochem. J. 431 (2010) 345-351.

[11] R.A. Schnell, P.A. Lefebvre, Isolation of the Chlamydomonas regulatory gene NIT2 by transposon tagging, Genetics 134 (1993) 737-747.

[12] E.H. Harris, The Chlamydomonas Sourcebook: A Comprehensive Guide to Biology and Laboratory Use, Academic Press, San Diego, 1989.

[13] K. Shimogawara, S. Fujiwara, A.R. Grossman, H. Usuda, High efficiency transformation of Chlamydomonas reinhardtii by electroporation, Genetics 148 (1998) 1821-1828.

[14] W. Pootakham, D. Gonzalez-Ballester, A.R. Grossman, Identification and regulation of plasma membrane sulfate transporters in Chlamydomonas, Plant Physiol. 153 (2010) 1653-1668.

[15] D. Gonzalez-Ballester, W. Pootakham, F. Mus, W. Yang, C. Catalanotti, L. Magneschi, A.D. Montaigu, J.J. Hiigurera, M. Prior, A. Galvan, E. Fernandez, A.R. Grossman, Reverse genetics in Chlamydomonas: a platform for isolating insertional mutants, Plant Methods 7 (2011) 24-36.

[16] S. Rozen, H.J. Skaletsky, S. Krawertz, S. Misener, Bioinformatics Methods and Protocols: Methods in Molecular Biology, Humana Press, Totowa, NJ, 2000.

[17] M. Seibert, D.K. Benson, T. Flynn, Method and apparatus for rapid biohydrogen phenotypic screening of microorganisms using a chemochromic sensor US Patent 6277,589 B1, Midwest Research Institute, Kansas City, MO, 2001.

[18] M.C. Posewitz, P.W. King, S.L. Smolinski, L. Zhang, M. Seibert, M.L. Ghirardi, Discovery of two novel radical $S$-adenosylmethionine proteins required for the assembly of an active [Fe] hydrogenase, J. Biol. Chem. 279 (2004) 25711 25720.

[19] X. Jiang, D. Stern, Mating and tetrad separation of Chlamydomonas reinhardtii for genetic analysis, J. Vis. Exp. (2009) e1274.

[20] R. Werner, D. Mergenhagen, Mating type determination of Chlamydomonas reinhardtii by PCR, Plant Mol. Biol. Rep. 16 (1998) 295-299.

[21] S.M. Newman, J.E. Boynton, N.W. Gillham, B.L. Randolph-Anderson, A.M Johnson, E.H. Harris, Transformation of chloroplast ribosomal RNA genes in Chlamydomonas: molecular and genetic characterization of integration events, Genetics 126 (1990) 875-888.

[22] D. Stevens, J. Rochaix, S. Purton, The bacterial phleomycin resistance gene ble as a dominant selectable marker in Chlamydomonas, Mol. Gen. Genet. 251 (1996) 23-30.

[23] I. Yacoby, S. Pochekailov, H. Toporik, M.L. Ghirardi, P.W. King, S. Zhang Photosynthetic electron partitioning between [FeFe]-hydrogenase and ferredoxin:NADP+-oxidoreductase (FNR) enzymes in vitro, Proc. Natl. Acad. Sci. USA 108 (2011) 9396-9401.

[24] M.S.A. Wecker, J.E. Meuser, M.C. Posewitz, M.L. Ghirardi, Design of a new biosensor for algal $\mathrm{H}_{2}$ production based on the $\mathrm{H}_{2}$-sensing system of Rhodobacter capsulatus, Int. J. Hydrogen Energy 36 (2011) 11229-11237. 
[25] M.L. Ghirardi, P. King, S. Kosourov, M. Forestier, L. Zhang, M. Seibert Development of algal systems for hydrogen photoproduction: addressing the hydrogenase oxygen-sensitivity problem, in: A. Collings, C. Critchely (Eds.), Artificial Photosynthesis: From basic Biology to Industrial Application, Wiley-VCH Verlag GmbH and Co., KGaA, Wienheim, 2006, pp. 211-227.
[26] T. Happe, J.D. Naber, Isolation, characterization and N-terminal amino acid sequence of hydrogenase from the green alga Chlamydomonas reinhardtii, Eur. J. Biochem. 214 (1993) 475-481.

[27] F. Mus, A. Dubini, M. Seibert, M.C. Posewitz, A.R. Grossman, Anaerobic acclimation in Chlamydomonas reinhardtii, J. Biol. Chem. 282 (2007) 2547525486. 